\title{
The Gendered Division of Labor in Brazilian Political Science Journals
}

\author{
Marcia Rangel Candido ${ }^{1}$ \\ https://orcid.org/0000-0003-3466-000X \\ Luiz Augusto Campos ${ }^{1}$ \\ https://orcid.org/0000-0003-2153-547X \\ João Feres ${ }^{1}$ \\ https://orcid.org/0000-0002-5830-0458
}
${ }^{1}$ Universidade do Estado do Rio de Janeiro, Institute of Social and Political Studies, Rio de Janeiro/RJ, Brazil

This article analyzes the gendered division of labor in Brazilian political science. We seek to answer two questions: what are the predominant topics in political science that are being published in the discipline's journals? How are women and men's authorship distributed in these journals? The methodology involved three stages. First, we built a corpus with 2,363 articles that were classified as 'political science and international relations' by the Coordination for the Improvement for Higher Education Personnel (Coordenação de Aperfeiçoamento de Pessoal de Nível Superior - CAPES) and published in the most prominent Brazilian journals between 2005 and 2018. Next, we scraped abstracts and other bibliographic information from publications in the Scientific Electronic Library Online (SciELO) platform and used a topic modeling technique to identify the most recurrent topics. Finally, we associated the identified topics with the authors' gender. The data was examined based on two specific types of the gendered division of labor: the 'horizontal' and the 'vertical'. Our results show that women and men as first authors tend to cluster around specific topics (horizontal division), but we did not find a tendency in journals to reject works on the topics in which women are better represented. In other words, differently from what was found by the international literature, the Brazilian journals in our sample do not seem to grant a lower status to these topics (vertical division). It is noteworthy, however, that men are the majority of first authors in all topics, including feminism.

Keywords: Political science; gendered division of labor; topics in political science; inequalities; journals.

http://doi.org/10.1590/1981-3821202100030002

For data replication, see: https://doi.org/10.7910/DVN/01SJV5

Correspondence: Marcia Rangel Candido. E-mail: marciarangelcandido@gmail.com

This publication is registered under a CC-BY Licence.

Funding information: Conselho Nacional de Desenvolvimento Científico e Tecnológico (CNPq); Coordenação de Aperfeiçoamento de Pessoal de Nível Superior (Capes); Fundação Carlos Chagas Filho de Amparo à Pesquisa do Estado do Rio de Janeiro and Instituto da Democracia e da Democratização da Comunicação (INCT). 


\section{A} lthough gender inequalities in labor relations do not always materialize in the same way in different geographical areas (FERGUSON, 2013), male over representation within political science can be considered a global phenomenon. Several studies across the world have shown that men hold the most important positions in the production and circulation of knowledge in the discipline, whether in teaching (BATES, JENKINS, and PFLAEGER, 2012; CANDIDO, FERES JUNIOR, and CAMPOS, 2019; CARPIUC, 2016), editing journals (MACEDO and CANDIDO, 2019; STEGMAIER, PALMER, and van ASSENDELFT, 2011), or publishing books and articles (CARPIUC, 2016; MATHEWS and ANDERSEN, 2001; MENDES and FIGUEIRA, 2019; SAMUELS and TEELE, 2018). In addition to acknowledging the quantitative evidence of gender inequalities within the academic community, we must also recognize how certain social groups are included - or find opportunities - in collective spaces.

The first and most explicit of these inequalities derives from the sexual division of labor and the separation between public and private spheres. Historically, it was up to men to carry out public functions, which are perceived as being more productive and socially important, while women were left with care work, which is often linked to the domestic sphere and is virtually always unpaid. Despite several transformations in the labor market and the progressive inclusion of women, the domestic work within the household and the family - in its various configurations - still take more of women's time than their opposite-sex peers, who, in turn, have more time to advance their professional careers (BIROLI, 2016; FERGUSON, 2013; KERGOAT, 2009).

Academia, in general, and the social sciences, in particular, are not an exception. In a survey of the habits of social scientists in Brazilian graduate schools, Marina Cordeiro (2017) found that, even in an area often concerned with inequality, women suffer greatly from the demands of marriage and motherhood. The unequal allocation of time between men and women, however, is not the only notorious consequence of the sexual division of labor. There is also the fact that gender inequalities are socially created, with expectations falling differently on men and women, which in turn affects their respective opportunities and experiences (BIROLI, 2016; FERGUSON, 2013; KERGOAT, 2009).

To contribute to this debate, we explore the gendered division of labor within the Brazilian political science community. Despite the availability of demographic 
information on the composition of this community (CANDIDO, FERES JUNIOR, and CAMPOS, 2019; MENDES and FIGUEIRA, 2019), it is still unknown whether journals' biases against specific topics could be hindering the inclusion of women in the Brazilian academic community. To address this issue, we examined articles that were published in the most prestigious political science journals. This examination is justified for two reasons. First, the circulation of articles is particularly important to advance the career of Brazilian political scientists, not only because publication rate is an important criterion for research productivity assessments, but also because it is central for disseminating research results (LEITE and CODATO, 2013). Second, the examination of these journals allows us to identify the most prevailing topics in published articles and to assess the female representation within these topics.

Scholars dedicated to the examination of the gendered division of labor faces the double challenge of determining which topics are to be considered 'male' or 'female' and measuring their respective prestige. In that respect, some authors stress that less cautious definitions tend to associate what is masculine with what is most socially valued (GOODWIN, BATES and McKAY, 2020; PANSARDI and VERCESI, 2017). There are numerous ways to categorize academic roles and fields, and that is done with the use of controversial and discretionary criteria. To give one example from within the political science community, it is usual for quantitative research and 'hard' approaches to be associated with the masculine, while qualitative research and 'soft' approaches are commonly associated with the feminine and allegedly undervalued in the field. Even though such an association does exist as a general impression in academia, taking it as an analytical key could reinforce rather than challenge such a stereotype.

The distinction between 'vertical' and 'horizontal' gendered division of labor improves our understanding of the different mechanisms underpinning these inequalities. When we talk about the vertical division of labor, we refer to issues of prestige, power, and status that derive from several aspects of the work relations in a given occupational group, such as salaries, hierarchical positions, or participation in more prestigious subfields. Drawing on this last aspect of the vertical division, we identified the topics in Brazilian political science and looked into their circulation in the form of published articles in academic journals. A topic was defined as prominent when it is more regularly published in the best Brazilian political science 
journals. By contrast, those topics with lower acceptance will be treated as marginalized in the discipline.

The horizontal division, on the other hand, considers the clustering of men and women in different topics. To address the horizontal division, we considered the gender distribution of the first authors across topics. Except for the articles that list the authors' names alphabetically, first authors tend to be research coordinators or experienced scholars in specific subfields. First, we consider the hypothesis of a strong horizontal gendered division, with women being concentrated on certain topics and men on others. Second, we consider the hypothesis of a vertical division, with a greater proportion of women working on topics that are less prestigious in the journals. It is noteworthy that both types of the gendered division of labor in authorship were found in the American academic community (KEY and SUMNER, 2019; TEELE and THELEN, 2017; YOUNG, 1995). How they occur in Brazil is still unknown.

This article is divided into four sections. First, we examine the literature on gender inequalities in political science. Second, we discuss our methodology, indicating our parameters for selecting the journals and explaining the technique used in the analysis (topic modeling). Third, we present the results and discuss the different types of the gendered division of labor among political scientists. Finally, we conclude by considering the general contributions of our research to the Brazilian and international debate.

\section{Studies on gender inequalities in political science}

The debate on gender inequalities gained particular attention in the discipline of political science at the turn of the 21st century, with the increased regularity of publications on the topic and the dissemination of empirical work across the world. Antecedents of this history can be seen in some isolated and broad research initiatives, such as Heloísa Michetti and Maria Teresa Miceli's (1969) ${ }^{1}$ decision to include gender as a variable in a broad survey of the beginning of political science in Brazil, and the development of specific subfields committed to discussing the underrepresentation of certain groups - an initiative that would later gain support from professional

${ }^{1}$ The author is currently known for another surname: Maria Teresa Kerbauy.

$$
\text { (2021) } 15(3) \quad \text { e0002-4/33 }
$$


associations ${ }^{2}$. Such support from the professional associations is important to promote this topic within the discipline because they have the capacity to foster professional networks, organize conferences, promote academic journals, and disseminate information about the career of a political scientist.

The problem with the initiatives coordinated by professional associations to assess the inequalities in the discipline is that, to a large extent, they are restricted to the global North. A search for information on inequalities resulted in findings from official reports by the American Political Science Association (APSA - in 2004, 2011; VAN ASSENDELFT et al., 2019); the European Consortium for Social Research (ECPR - in 2016, 2017, and 2018) and the International Political Science Association (IPSA - ABU-LABAN, SAWER and ST-LAURENT, 2018; LINDROOS et al., 2014; MATONYTE, SAWER and ST-LAURENT, 2012)33. South American political science, however, lacks similar initiatives by local professional associations. The 'Associação Brasileira de Ciência Política' (ABCP - Brazilian Association of Political Science) and the 'Sociedad Argentina de Análisis Político' (SAAP - Argentine Society for Political Analysis) started a similar initiative, but they have not published many results ${ }^{4}$. In addition, academic articles addressing gender inequalities in Brazil are rare and mainly descriptive, providing few explanations for these phenomena (CAMPOS, FERES JÚNIOR, and GUARNIERI, 2017; CANDIDO, FERES JÚNIOR and CAMPOS, 2019; MENDES and FIGUEIRA, 2019).

The international literature on gender inequalities within political science has shown that women are increasingly present in undergraduate and graduate programs but not as professors or holders of higher-level positions in the academic career. This phenomenon is known by the expression 'leaky-pipeline' (ABELS and WOODS, 2015; APSA, 2004; BATES, JENKINS, and PFLAEGER, 2012; CARPIUC, 2016;

${ }^{2}$ See, for example, the Committee on the Status of Women in the Profession, linked to APSA. Consulted at <http://web.apsanet.org/cswp/>. Accessed on October, 5th, 2019.

${ }^{3}$ Additional reports on inequalities are signed by these associations, and they are formally released on the institutions' websites. See the APSA's reports at: $<$ https://www.apsanet.org/reports>; the ECPR's at <https://ecpr.eu/contentpage.aspx?id=458>; the IPSA's at <https://www.ipsa.org/publications/ipsa-gender-diversity-monitoring-report>. Accessed on October, $01,2019$.

${ }^{4}$ The ABCP has been conducting a series of interviews with renowned female political scientists, in addition to other initiatives to promote studies on gender and science. Moreover, the association has determined that proponents of round tables must ensure gender parity in its upcoming congress. The SAAP, in turn, started to gather data on harassment and gender discrimination based on surveys that were carried out with participants in the Society's congress edition of 2019. 
ELIZONDO, 2015; FERNÁNDEZ, 2006; MONROE and CHIU, 2010), a metaphor for how female inclusion at the beginning of the academic career dissipates along the path that leads to the top.

Moreover, studies show that women participate less in their countries' professional associations (ABU-LABAN, SAWER and ST-LAURENT, 2018; CARPIUC, 2016; ELIZONDO, 2015; FERNÁNDEZ, 2006), publish, on average, fewer articles and books than men (CARPIUC, 2016; ELIZONDO, 2015; FERNÁNDEZ, 2006; MATHEWS and ANDERSEN, 2001; SAMUELS e TEELE, 2018; TEELE and THELEN, 2017; WILLIAMS et al., 2015), and appear less in award lists (BRANDES et al., 2001), academic citations (DION and MITCHELL, 2019; DION, SUMNER, and MITCHELL, 2018; MITCHELL, LANGE and BRUS, 2013), and course syllabi (COLGAN, 2017). In addition to the female gender being a minority in scientific congresses in the discipline, it is usual to have roundtables and panels made up exclusively of men (BREUNING and LU, 2010; MARQUES, 2016). Such numerous forms of inequalities are noticed by those who suffer from them: women report more discrimination in professional interactions than men (ALLEN and SAVIGNY, 2016; AKHTAR et al., 2005; KANTOLA, 2015, 2008).

Qualitative studies have investigated the causes of the leaky-pipeline phenomenon. Parveen Akhtar et al. (2005) analyzed political science institutions in the United Kingdom and identified four types of professional challenges commonly faced by scholars of both genders: concerns about financial issues, concerns about making an impact on the field, lack of information about work practices, and lack of self-confidence. Lack of self-confidence is more often reported by women, who are also particularly affected by the demands of domestic and family life, by time constraints, by gender stereotypes, and by their deviation from the male standard, which is implicit in the best institutional positions.

In her influential 'Theory of Gendered Organizations', Joan Acker (1990) postulates that professional institutions are underpinned by both an abstract notion of worker and a presumed sense of gender neutrality, which favor and reflect the male body and sexuality. The author highlights the social production of gender structures that undermine women in daily interactions, such as occupational distinctions, job positions, and expectations in behavior. Drawing on this theory, Johanna Kantola (2008) presents results from the observation of inequalities specifically within political science. To explain the decline in female representation throughout the 
academic career, Kantola (2008) developed a survey and interviewed former students from Finland's largest political science department, at the University of Helsinki. The study's conclusions highlighted three types of interactions that Acker's theory (1990) had previously identified: 01 . the division of labor, with women receiving few incentives for undertaking activities that are valued by the country's scientific community, such as teaching, 02. the hierarchical socializations that create strong barriers to women, with men more often than women taking the role of advisers, building professional networks, and creating opportunities, and, finally, 03. the association of symbols with social groups, which creates different opportunities for men and women, establishes a hierarchical classification of research topics, or distrusts female expertise.

The literature on the gender gap in political science has expanded in recent decades. A substantial share of the research studies on this topic began to be published in journals linked to the APSA and the ECPR, both of which published a series of works revealing that women are underrepresented in the most prominent political science journals (BREUNING and SANDERS, 2007; CARPIUC, 2016; EVANS and MOULDER, 2011; KONIG and ROPERS, 2018; TEELE and THELEN, 2017; YOUNG, 1995; WILLIAMS et al., 2015). Researchers in peripheral countries replicated these studies and found a similar pattern of inequalities, suggesting that these inequalities exist regardless of the scientific communities' position in the geopolitics of knowledge (CAMPOS, FERES, and GUARNIEIRI, 2017; CARPIUC, 2016; CURTIN, 2013; FERNÁNDEZ, 2006; MENDES and FIGUEIRA, 2019).

Studies addressing the issue of gender gap usually focus on the authors' gender not only because academic journals are an important site of communication and prestige within the discipline, but also because their evaluation systems are presumed to be 'blind' to the social and political hierarchies among researchers. Used by the vast majority of the most qualified and renowned journals, the blind peer-review process has become hegemonic. While keeping the authors' total or partial anonymity, this model would in theory guarantee that intrinsic characteristics of scholars, such as gender or race, are not considered when assessing the quality and suitability of their scientific work.

The reality, however, is distant from the ideal. The gender gap in authorship not only reflects how job opportunities are unequally distributed in academia but, in 
some ways, also aggravates the problem. In other words, the underrepresentation of female authors in prominent journals cannot simply be seen as a mirror of the smaller share of women who are professional political scientists (TEELE and THELEN, 2017). Several reasons have been mentioned to explain the phenomenon: from the academic journals' biases in favor of topics that are preferably addressed by men, and the different number of submissions by gender, to the difference in perceptions reported by women and men on their chances of approval in specific journals (BROWN et al., 2019; DJUPE, SMITH and SOKHEY, 2018; SAMUELS and TEELE, 2018; TEELE and THELEN, 2017).

Dawn Teele and Kathleen Thelen's (2017) study is notorious for prompting political science journals to justify the gender inequalities found in their publication patterns and to disseminate information about their submission processes. After examining ten prominent political science journals, Teele and Thelen (2017) identified three publication patterns: severe underrepresentation of female authors even when considering the low percentage of female professors in the field, high frequency of allmale collaboration, and less receptivity by the journals to qualitative methods, which is disproportionately preferred by women.

Editors of five journals - 'American Political Science Review', 'Comparative Political Studies', the 'World Politics', 'Political Behavior', and 'International Studies Quarterly' - commented on the results of Teele and Thelen (2017) and asked whether the gender inequalities they found could be explained by discrimination in the editorial process. According to these editors, the most persistent obstacle in promoting gender diversity is the smaller number of manuscripts written by women submitted for evaluation as compared to those by men (BROWN et al., 2019; KONIG and ROPERS, 2018; PETERSON, 2018; SAMUELS, 2018; TUDOR and YASHAR, 2018).

To further understand gender inequalities in submissions, other scholars tried to capture the perceptions that men and women have of the journals' profiles and of the likelihood of having a work published in one of the discipline's venues, finding that perceptions vary significantly according to the gender of the respondent. One of the suggested causes of gender inequality in submissions is women's aversion to the risk of having their articles refused in journals that are perceived to be biased against their work (DJUPE, SMITH and SOKHEY, 2018; BROWN et al., 2019). What could also explain the phenomenon, according to David Samuels and Dawn Teele (2018), is the higher 
degree of demand and pressure that women place on themselves for achieving quality work (HENGEL, 2017 apud SAMUELS and TEELE, 2018) and the overload of academic administrative service (ALTER et. al, 2018 apud SAMUELS and TEELE, 2018).

Ellen Key and Jane Sumner (2019) proposed a different - although not irreconcilable - explanatory hypothesis. They argue that while the academic community is aware of gender inequalities in submissions and publications, they ignore that women and men have different preferences in terms of methodology and topic. To explore this issue, the authors focused their analysis on political science Masters dissertations, assuming that, in this type of work, students have more autonomy to choose their topics of research, as opposed to research articles, which are submitted to the journals' norms and editorial policies, as well as to the constraints of multiple authorship. Their results indicate that most - but not all - topics do well in terms of gender balance. Women are overrepresented in topics such as gender, race, health, narrative and discourse, and types of government; men, on the other hand, are overrepresented in topics such as critical theory, vote, interstate war, and partisanship. The topics in which men are in the lead, however, are precisely those with more space and prestige in the discipline's most prominent academic journals. Therefore, underrepresentation of women in academic journals is possibly associated with the way scholars are distributed across the various topics and also how prestigious each topic is within the political science community: those topics mostly favored by men are more highly regarded in journals, while those mostly favored by women are less valued (KEY and SUMNER, 2019).

Other studies corroborate the existence of gender inequalities within political science (DION and MITCHELL, 2019; MATHEWS and ANDERSEN, 2001; REID and CURY, 2019; YOUNG, 1995). These studies, however, are restricted to developed countries; a similar work has not yet been done in Latin America. It is noteworthy that the interest in studying gender inequalities remains low in the region despite the growing number of works on the history and institutionalization of Latin American political science, (BULCOURF, MÁRQUEZ and CARDOZO, 2015), indicating that this 'gap' in knowledge is due to the issue of gender inequalities being insufficiently addressed by the Latin American scientific communities. 
To contribute to this debate, we combined two sets of studies that have developed within the Brazilian academic literature and were, until now, poorly articulated: one dedicated to identifying the subfields and methodological preferences within the Brazilian political science community (LEITE, 2016; NICOLAU and OLIVEIRA, 2017), and the other dedicated to providing data for the assessment of gender inequalities in submissions and publications within academic venues (BRINGEL, 2016; MENDES and FIGUEIRA, 2019).

While a researcher may choose to compare the contexts of relatively different countries and find similarities between them, focusing on case studies within a country enables the discovery of singularities that can shed light on new generalizable aspects. Kantola (2015), for instance, pointed out that shifts in government policies and university funding in Finland affected gender relations, with negative effects on women. The author, thus, identified a variable that is usually ignored by studies on inequalities in political science: the external interferences of science-related policies. Fernández (2006), on the other hand, stressed similar conditions experienced by female political scientists in Chile and in other countries where the discipline was institutionalized during the democratic transition.

In Brazil, researching and teaching political science is essentially done at public universities, where candidates must pass a public competition to become a professor and start a career that, in comparison to private universities, has a high level of stability. Women continue to be professors possibly because of these particularities; however, mechanisms to tackle gender inequalities are not used to select professors in Brazilian universities. Women and men experience the same demand for productivity, which is measured mainly by their publication rates in prominent journals. Thus, despite possibly working double or triple shifts and dealing with maternity obligations, women must meet the same goals as men - while men have more time to advance their careers. As the theory of Joan Acker (1990) postulates, entering professional organizations entails adapting to an abstract notion of an ideal worker who, in reality, mirrors the life conditions of men.

Female professors in Brazilian graduate programs in political science are clearly and highly underrepresented, which is not seen in neighboring fields, such as sociology and anthropology. Women represent only 33\% of the overall number of professors in political science, in contrast to $47 \%$ of the sociologists and $54 \%$ of the 
anthropologists (CANDIDO, FERES JÚNIOR, and CAMPOS, 2019). To promote more diversity in the field, it is crucial to identify its inequalities, which, in turn, require researchers to be in dialogue with similar studies carried out both in Brazil and other countries. Inspired by studies that draw an association between women's lower publication rates and topics in political science (KEY and SUMNER, 2019; TEELE and THELEN, 2017; YOUNG, 1995), we investigated how receptive the Brazilian political science journals were to different topics and whether the patterns we found could be associated with obstacles for women's inclusion - obstacles that have a high impact on their academic career.

\section{Metodology}

Our corpus included 2,363 academic articles that were published between 2005 and 2018 in journals at the SciELO, the main online platform of scientific journals in Brazil and one of the most important in America Latin ${ }^{5}$. We selected the journals that were classified as belonging to the field of 'Political Science and International Relations' (CP\&RI) in the assessment made in 2019 by the CAPES, an agency of the Brazilian Ministry of Education that is responsible for the evaluation of higher education professionals. CAPES classified these journals as CP\&RI in two stages. First, the agency examined the field of affiliation of the authors who published the most in each journal, distributing them to the respective specialized evaluation committees. Then, the CAPES committees, which are composed of representatives and consultants of each field, considered whether the distribution was appropriate, eventually requesting the reallocation of some journals to other fields ${ }^{6}$. It is noteworthy that several interdisciplinary journals were included in our sample due to the predominance of political scientists among their authors. Eight publications met these criteria:

- Brazilian Political Science Review (BPSR): created in 2007 by the Brazilian Political Science Association (Associação Brasileira de Ciência Política - ABCP); it publishes scientific articles only in English;

\footnotetext{
${ }^{5}$ We would like to thank Thyago Simas for his assistance in creating the algorithm for scraping data from the SciELO platform and André Félix for his assistance in using the tool to assign a gender to the authors' names.

${ }^{6}$ The political science committee considered a list of journals that had published more articles by political scientists; their selected list of journals was given to us by members of this committee.
} 
- Contexto Internacional (CI): published since 1985 by the Institute of International Relations (Instituto de Relações Internacionais - IRI) of the Pontifícia Universidade Católica do Rio de Janeiro (PUC-RJ); most of its articles focus on international relations; - DADOS - Revista de Ciências Sociais: created in 1966, it is edited by the Institute of Social and Political Studies of the Universidade do Rio de Janeiro (Instituto de Estudos Sociais e Políticos da Universidade do Estado do Rio de Janeiro - IESP/UERJ). Despite being an interdisciplinary journal, most of its articles are from the fields of political science and sociology;

- Novos Estudos (NE-CEBRAP): created in 1981, it is edited by the Brazilian Center of Analysis and Planning (Centro Brasileiro de Análise e Planejamento - CEBRAP). Despite being an interdisciplinary journal within the humanities, most of its authors who published during the period analyzed were political scientists;

- Opinião Pública (OP): published since 1993 by the Center for Studies on Public Opinion (Centro de Estudos de Opinão Pública - CESOP) at the Universidade Estadual de Campinas (Unicamp), with articles focusing on methodology, political behavior, and other topics in political science;

- Revista Brasileira de Ciência Política (RBCP): created in 2009, it is edited by the Institute of Political Science (Instituto de Ciência Política - IPOL) of the Universidade de Brasília (UnB);

- Revista Brasileira de Política Internacional (RBPI): created in 1958 by the Brazilian Institute of International Relations (Instituto Brasileiro de Relações Internacionais IBRI), a non-governmental organization that currently operates in Brasilia; its articles are in English and mostly focus on international relations;

- Revista de Sociologia e Politica (RSP): created in 1993, it is edited by the Graduate Program in Political Science of the Universidade Federal do Paraná (UFPR).

Since most of these journals were included in the SciELO's portfolio in 2005, we selected those issues that were published between 2005 and 2018. We excluded articles without an abstract in English (usually, editorial notes, translations, interviews, etc) and those whose abstracts had less than 300 characters - such exclusion is justified because such small abstracts tend to accompany some type of non-scholarly manuscript. Furthermore, the topic modeling technique requires a certain number of words to function properly. Table 01 shows the distribution of the analyzed articles by year and journal.

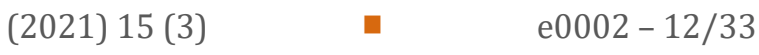


Table 01. Distribution of articles in the corpus by year and journal (2005-2018)

\begin{tabular}{|c|c|c|c|c|c|c|c|c|c|c|c|c|c|c|c|c|}
\hline & 2005 & 2006 & 2007 & 2008 & 2009 & 2010 & 2011 & 2012 & 2013 & 2014 & 2015 & 2016 & 2017 & 2018 & Total & $\%$ \\
\hline BPSR & & & & & & & & 04 & 17 & 13 & 18 & 22 & 19 & 18 & 111 & $(4.7 \%)$ \\
\hline Contexto Internacional & 10 & 10 & 09 & 15 & 15 & 19 & 18 & 18 & 18 & 21 & 31 & 32 & 31 & 24 & 271 & $(11.5 \%)$ \\
\hline Dados & 24 & 26 & 25 & 30 & 28 & 27 & 26 & 29 & 30 & 34 & 32 & 33 & 31 & 28 & 403 & $(17.1 \%)$ \\
\hline Novos Estudos & 19 & 33 & 33 & 34 & 28 & 26 & 19 & 16 & 23 & 22 & 07 & 18 & 24 & 21 & 323 & $(13.7 \%)$ \\
\hline $\mathrm{OP}$ & 15 & 13 & 12 & 17 & 17 & 19 & 17 & 23 & 18 & 24 & 26 & 25 & 27 & 23 & 276 & (11.7\%) \\
\hline RBCP & & & & & & & 23 & 28 & 26 & 30 & 30 & 28 & 29 & 22 & 216 & (9.1\%) \\
\hline RBPI & 17 & 19 & 15 & 19 & 17 & 31 & 20 & 28 & 18 & 36 & 20 & 16 & 31 & 23 & 310 & $(13.1 \%)$ \\
\hline RSP & 24 & 17 & 23 & 39 & 39 & 39 & 49 & 47 & 37 & 34 & 28 & 28 & 28 & 21 & 453 & (19.2\%) \\
\hline Total & 109 & 118 & 117 & 154 & 144 & 161 & 172 & 193 & 187 & 214 & 192 & 202 & 220 & 180 & 2.363 & $(100 \%)$ \\
\hline
\end{tabular}

Sources: Elaborated by the authors. 
We assigned topics to the articles in the corpus with a topic modeling technique, which is used to identify semantic patterns in scientific articles (taken as units of analysis) by forming groups of terms with most co-occurrence. We used the LDA package (Latent Dirichlet Allocation) in R programming language to bring certain documents together and, consequently, keep others apart (SCARPA, 2017).

Topic modeling operates in five stages. First, the set of documents to be analyzed is cleared of words without semantic relevance, keeping only the terms with some meaning. Numerals, pronouns, prepositions, words with less than two letters, etc are eliminated. Secondly, very common and very rare terms are excluded. This is necessary because none of these two classes of words contributes to the definition of minimally regular semantic patterns. The term 'article', for example, is so ubiquitous in the abstracts in our corpus that it would hardly help to characterize any topic; the same goes for a rare term like 'portfolio'. A third step consists of isolating the root words and eliminating the less semantically relevant suffixes and prefixes.

To estimate the number of topics for achieving the best clustering of articles in the corpus, we used the method based on the density of intersections via the LDA package, as proposed by Cao et al. (2009) - once again, in R programming language. With this method, an algorithm extracts from the corpus a certain number of different topics. This method assumes that the ideal number of topics is that in which the words belonging to more than one topic reach the optimum level. In other words, a certain number of topics are considered to be excessive when most of them are characterized by a large number of identical terms, and, conversely, the number of topics is considered insufficient when most of them have terms so specific that the intersection is too small. Thus, the optimal number of topics is established when there are some intersections - but not many - between the topics. In our case, the optimal number is 15 topics.

We used two outputs of the topic modeling process in our analysis. The first output is a list of topics that were detected in the articles, followed by the ten most recurring terms in each of these topics, as shown in Table 02. From these sets of terms, we can make an interpretative determination of the topics that they represent, as shown in the third column ('assigned label'). The second output is the definition of the predominant topic for each of the articles included in the corpus. In accordance with 
the topic modeling technique, we chose to work only with the predominant topic, although each article may have its vocabulary associated with more than one topic.

Table 02. Identified topics, recurring terms, and assigned label

\begin{tabular}{|c|c|c|}
\hline ID & Recurring terms & Assigned subfield \\
\hline 01 & $\begin{array}{l}\text { cultur, histori, thought, intellectu, domin, essay, contrast, time, } \\
\text { turn, produc, space, read, light, earli, dialogu, classic, natur, } \\
\text { move, bring, paradigm }\end{array}$ & $\begin{array}{l}\text { Brazilian political } \\
\text { thought }\end{array}$ \\
\hline 02 & $\begin{array}{l}\text { develop, econom, global, market, capit, economi, china, crisi, } \\
\text { industri, increas, financi, evolut, invest, growth, play, expans, } \\
\text { climat, grow, rise, produc }\end{array}$ & Political economy \\
\hline 03 & $\begin{array}{l}\text { parti, elector, elect, vote, candid, campaign, voter, presidenti, } \\
\text { ideolog, behavior, competit, profil, choic, data, literatur, } \\
\text { politician, opposit, disput, identif, municip }\end{array}$ & $\begin{array}{l}\text { Elections and political } \\
\text { parties }\end{array}$ \\
\hline 04 & $\begin{array}{l}\text { empir, methodolog, scienc, elit, method, media, literatur, } \\
\text { knowledg, employ, theoret, review, scientif, categori, corrupt, } \\
\text { academ, content, journal, frame, topic, criteria }\end{array}$ & $\begin{array}{l}\text { Public opinion and } \\
\text { media }\end{array}$ \\
\hline 05 & $\begin{array}{l}\text { polici, govern, program, administr, implement, public, privat, } \\
\text { municip, feder, adopt, environment, capac, manag, health, } \\
\text { servic, autonomi, regul, agenc, lula, local }\end{array}$ & Public policies \\
\hline 06 & $\begin{array}{l}\text { data, indic, factor, evalu, valu, hypothesi, variabl, test, measur, } \\
\text { determin, compar, signific, high, conduct, depend, four, } \\
\text { opinion, greater, assess, attitud }\end{array}$ & $\begin{array}{l}\text { Quantitative } \\
\text { methodology }\end{array}$ \\
\hline 07 & $\begin{array}{l}\text { secur, war, forc, militari, unit, peac, defens, despit, strateg, lack, } \\
\text { nuclear, conclud, address, arm, scenario, action, crime, threat, } \\
\text { polic, expect }\end{array}$ & Defense and security \\
\hline 08 & $\begin{array}{l}\text { democraci, concept, theori, democrat, critic, theoret, liber, } \\
\text { offer, attempt, section, reason, normat, definit, ideal, critiqu, } \\
\text { third, basi, conceptu, must, moral }\end{array}$ & Political theory \\
\hline 09 & $\begin{array}{l}\text { legisl, coalit, presid, execut, feder, control, court, agenda, } \\
\text { member, deputi, judici, parliamentari, whether, parliament, } \\
\text { decis, offic, congress, senat, increas, chamber }\end{array}$ & $\begin{array}{l}\text { Executive and } \\
\text { legislative relations }\end{array}$ \\
\hline 10 & $\begin{array}{l}\text { public, particip, part, civil, citizen, interact, actor, mechan, } \\
\text { account, space, council, participatori, legitimaci, good, adopt, } \\
\text { delib, literatur, communic, incorpor, environ }\end{array}$ & Political participation \\
\hline 11 & $\begin{array}{l}\text { women, educ, class, citi, inequ, school, labor, gender, famili, rio, } \\
\text { paulo, incom, urban, increas, access, worker, black, age, racial }\end{array}$ & Gender and feminism \\
\hline 12 & $\begin{array}{l}\text { state, nation, structur, major, demonstr, follow, unit, goal, caus, } \\
\text { neoliber, conclus, conclud, intervent, creation, initi, explan, } \\
\text { attempt, abl, strengthen, fundament }\end{array}$ & State and Nation \\
\hline 13 & $\begin{array}{l}\text { right, regim, law, discours, legal, justic, ident, struggl, } \\
\text { citizenship, demand, religi, name, republ, republican, protect, } \\
\text { freedom, materi, narrat, authoritarian, transit }\end{array}$ & Law and justice \\
\hline 14 & $\begin{array}{l}\text { action, activ, dynam, movement, actor, place, time, carri, type, } \\
\text { engag, interview, structur, argentina, mobil, common, follow, } \\
\text { open, natur, shape, communiti }\end{array}$ & $\begin{array}{l}\text { Collective action and } \\
\text { social movements }\end{array}$ \\
\hline 15 & $\begin{array}{l}\text { region, foreign, america, south, integr, trade, cooper, domest, } \\
\text { union, european, negoti, agreement, initi, sovereignty, africa, } \\
\text { mercosur, leadership, bric, multilater }\end{array}$ & $\begin{array}{l}\text { International relations } \\
\text { and foreign policy }\end{array}$ \\
\hline
\end{tabular}

Sources: Elaborated by the authors. 
In the last stage of data collection and analysis, we did an automated classification of the first authors' gender based on a dataset of the Brazilian Institute of Geography and Statistics (Instituto Brasileiro de Geografia e Estatística - IBGE) that estimates the gender of names with a high degree of certainty. We considered only first authors not just due to technical limitations, but also because including all authors would most likely have produced a false balance, as women generally publish more as second or third authors (CAMPOS, FERES JÚNIOR, and GUARNIERI, 2017). Because some ambiguous or foreign names were not recognized by the IBGE database, the coding had to be completed manually.

\section{Results}

As we can see in Graph 01, articles with a vocabulary associated with 'elections and political parties' predominated, corresponding to $9.6 \%$ of the corpus. In the second position are articles associated with the topic 'international relations and foreign policy', which, again, is not a surprising result, given the increasing autonomy of this topic, with its specific journals, graduate programs, and professional associations. Two of the journals in our sample are specialized in this topic: the 'Contexto Internacional' and the 'Revista Brasileira de Política Internacional'. In the third position are articles classified as 'political economy', a result that reflects the particular path of Brazilian political science, in which the debate on development with the collaboration of economists - has been especially prominent. (CAMPOS, FERES JÚNIOR, and GUARNIERI, 2017).

We found two surprising topics falling in intermediary positions. First, the number of articles focused on 'gender and feminism' (07\%). Despite being a topic in expansion, it was late recognized in legitimizing spaces within the political science community, such as congresses and graduate programs (MATOS, 2016) ${ }^{7}$. A reason that makes this result even more significant is that political scientists who work on gender and want to publish their work have the option of submitting their work to journals that were not included in our sample, journals that have good ratings on CP\&RI Qualis and are specifically dedicated to gender issues, such as 'Revista Estudos Feministas'

\footnotetext{
${ }^{7}$ Marlise Matos (2016) gathered the studies on gender within political science and observed that publications were increasing since 2006.
}

(2021) $15(3) \quad$ - $\quad 0002-16 / 33$


(REF) and 'Cadernos Pagu'8. The topic 'public opinion and media' was predominant in $6.1 \%$ of the articles, contrasting with findings from Antonio Teixeira de Barros and Lucas Silva (2017), who examined a larger set of journals and indicated that political scientists have a low engagement with this topic.

Secondary topics, on the other hand, have rather unclear publication patterns. 'State and nation' is a topic with articles focusing on the formation, consolidation, and operation of national states - a lingering topic that is not significantly addressed by the political science community. Studies on 'collective action and social movements', in turn, have experienced rapid growth in recent years (SZWAKO, DOWBOR, and ARAÚJO, 2020), but they still are a relatively minor topic in political science. It is noteworthy that this topic was 'split' into two separate groups in the topic modeling process, also creating the topic 'political participation'. In the topic list, positioned between 'collective action and social movements' and 'political participation', we have 'quantitative methodologies', a topic that has been increasingly discussed within the discipline, but still secondary compared to rather established topics.

We will now use the sequence of the assigned topics depicted in Graph 01 to hierarchically classify the topics in political science, that is, 'elections and political parties' is the most prestigious topic, followed by 'international relations and foreign policy', and so forth. After we verified the gender balance within each topic, we will use this hierarchical classification to assess the vertical division of labor.

Of the overall compiled articles, $30.2 \%$ had a woman as the first author, while $69.8 \%$ had a man in the lead. Over the period considered in the analysis, the proportion of women as first authors increased very slightly. Between 2005 and 2010, 72\% of the published articles had men as first authors, and 28\% had women as first authors; between 2011 and 2018, men were in the lead in $68 \%$ of the texts, while women were in the lead in 22\%: Graph 02 shows the timeline of female participation between 2005 and 2018.

${ }^{8}$ Such journals, however, are interdisciplinary, that is, they accept articles from several fields of knowledge. In a survey of the characteristics of articles that were published in the REF, Debora Diniz and Paula Foltran (2004) found insignificant participation of the political science field in the journal only $03 \%$ of the overall articles between 1992 and 2002. 
Graph 01. Percentage of texts in the corpus according to the assigned predominant topic

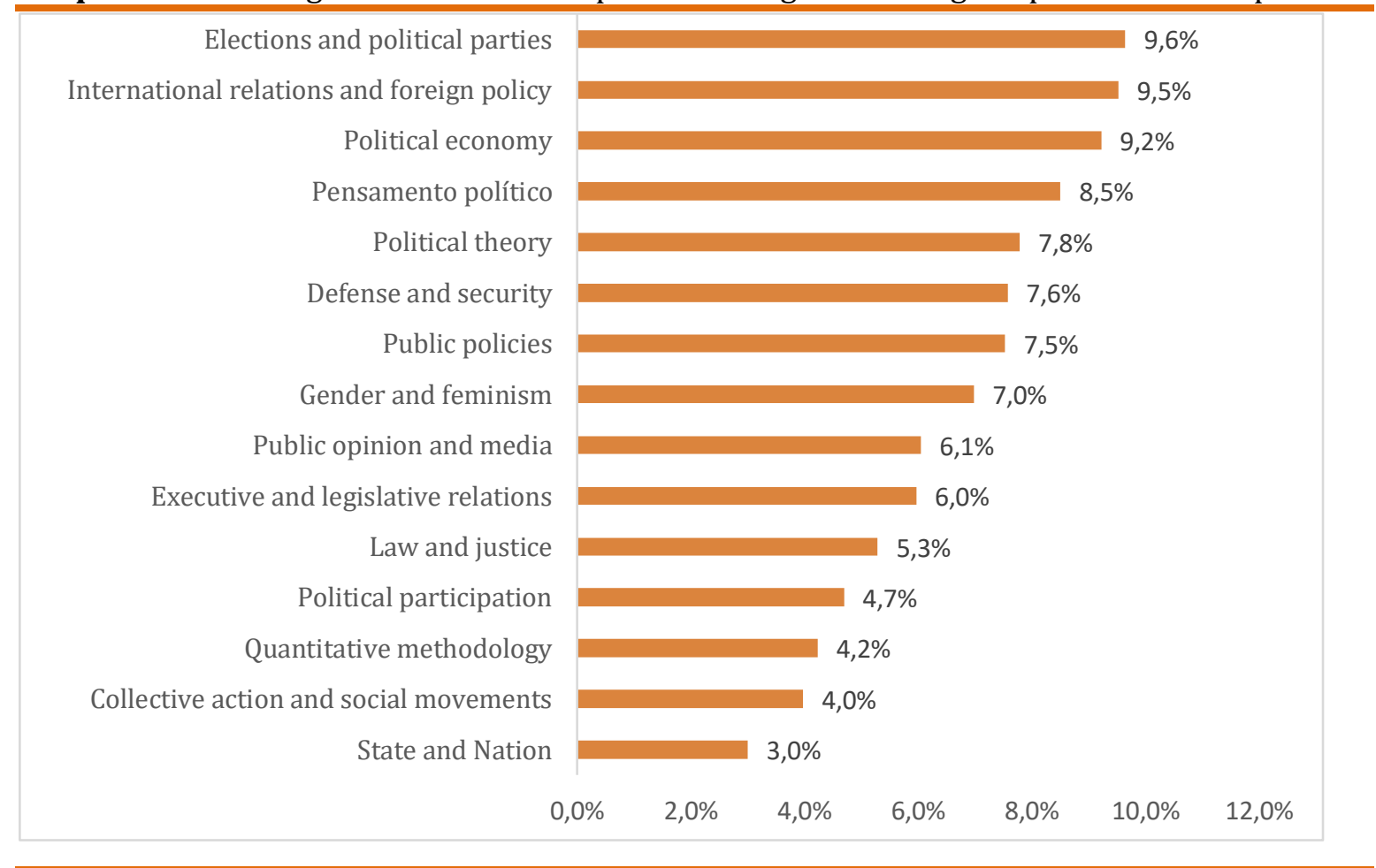

Source: Elaborated by the authors.

Graph 02. Percentage distribution of articles with female authors by year of publication

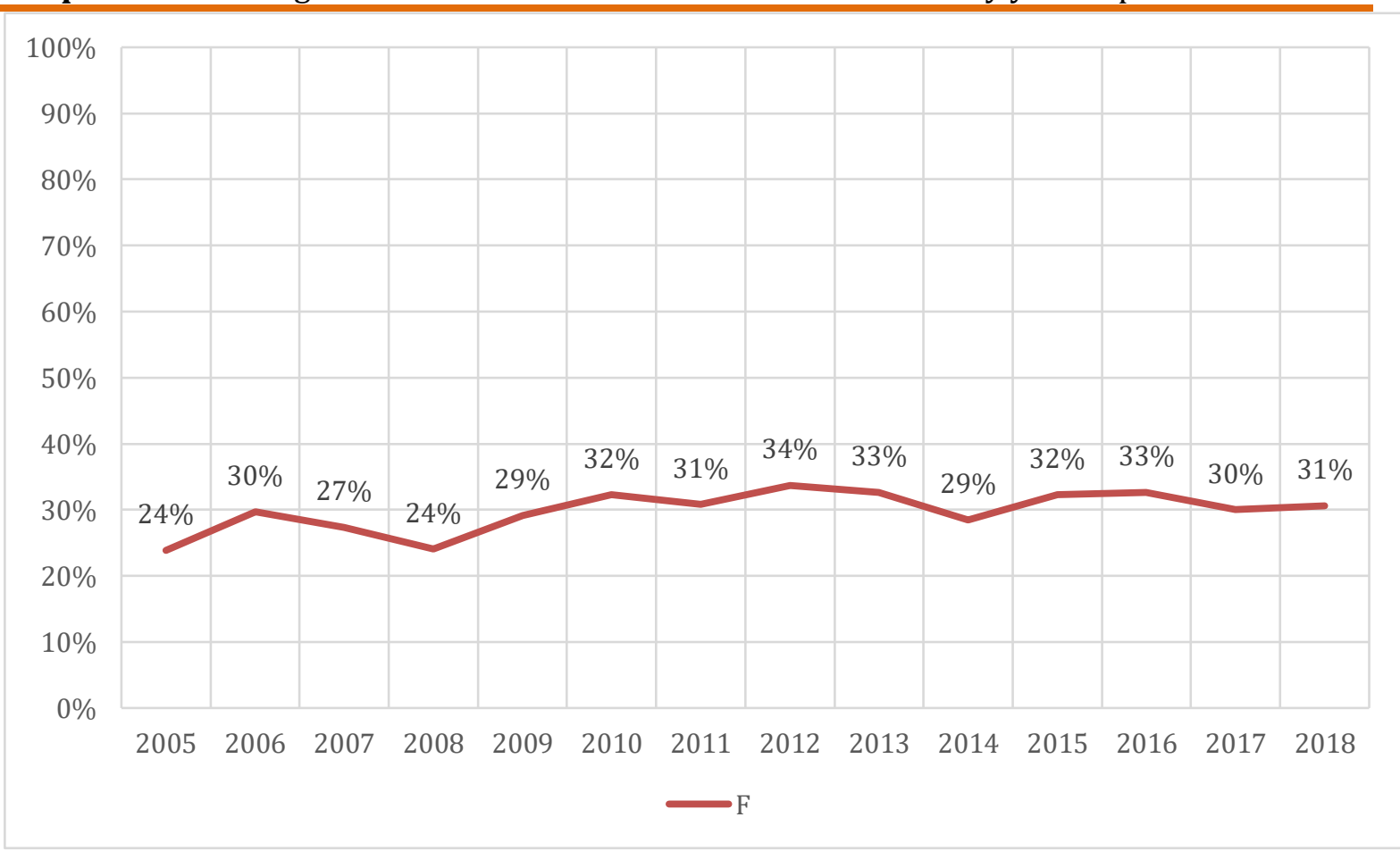

Source: Elaborated by the authors. 
In Graph 03, we see how the topics are distributed across each of the eight journals, which in turn provides us with a visual representation of the profile for each journal, based on the topic or topics in which the journals are focused. 'Opinião Pública' is the journal with more articles focused on 'elections and political parties', while the 'Novos Estudos' published more articles on 'Brazilian political thought'. 'Contexto Internacional' and 'Revista Brasileira de Política Internacional' share a similar profile, publishing research studies on 'international relations and foreign policy', 'defense and security', and 'law and justice'. The journal with the highest number of topics is 'Revista de Sociologia e Politica', followed by 'Dados' and 'Revista Brasileira de Ciência Política'. The 'Brazilian Political Science Review' also has a relatively well-balanced set of topics, although topics such as 'political economy', 'elections and political parties', and 'public policies' were privileged.

Graph 04 shows the horizontal division of labor, which is defined by the gender ratio of authors within each topic. One can see that the gender ratio varies considerably across topics. Articles with topics such as 'state and nation' and 'quantitative methodology' had about $20 \%$ of women as first authors, while articles focused on 'gender and feminism' or 'law and justice' are closer to parity, with more than $40 \%$ of articles with women as first authors. Still, it is noteworthy that, even in articles focused on gender inequalities and feminism, women are behind men in authorship. It is also true that articles addressing feminist issues may have also been linked to other topics during the topic modeling process (such as 'political theory', 'collective action', or 'political participation'), depending on the vocabulary used in the abstracts.

Equally important is the concentration of women in studies on 'law and justice'. That was a surprising result - it was expected that the representation of women would be higher within the topic of 'gender and feminism', given that women not only played a larger role in the genesis of this topic and in recent assessments on its progress, but they also publish more than men in the journals specially dedicated to gender and feminism (DINIZ and FOLTRAN, 2004; DION and MITCHELL, 2019; KEY and SUMNER, 2019; MATOS, 2016; REID and CURY, 2019; YOUNG, 1995). 


\section{Graph 03. Percentage distribution of articles according to the assigned topic and journal}

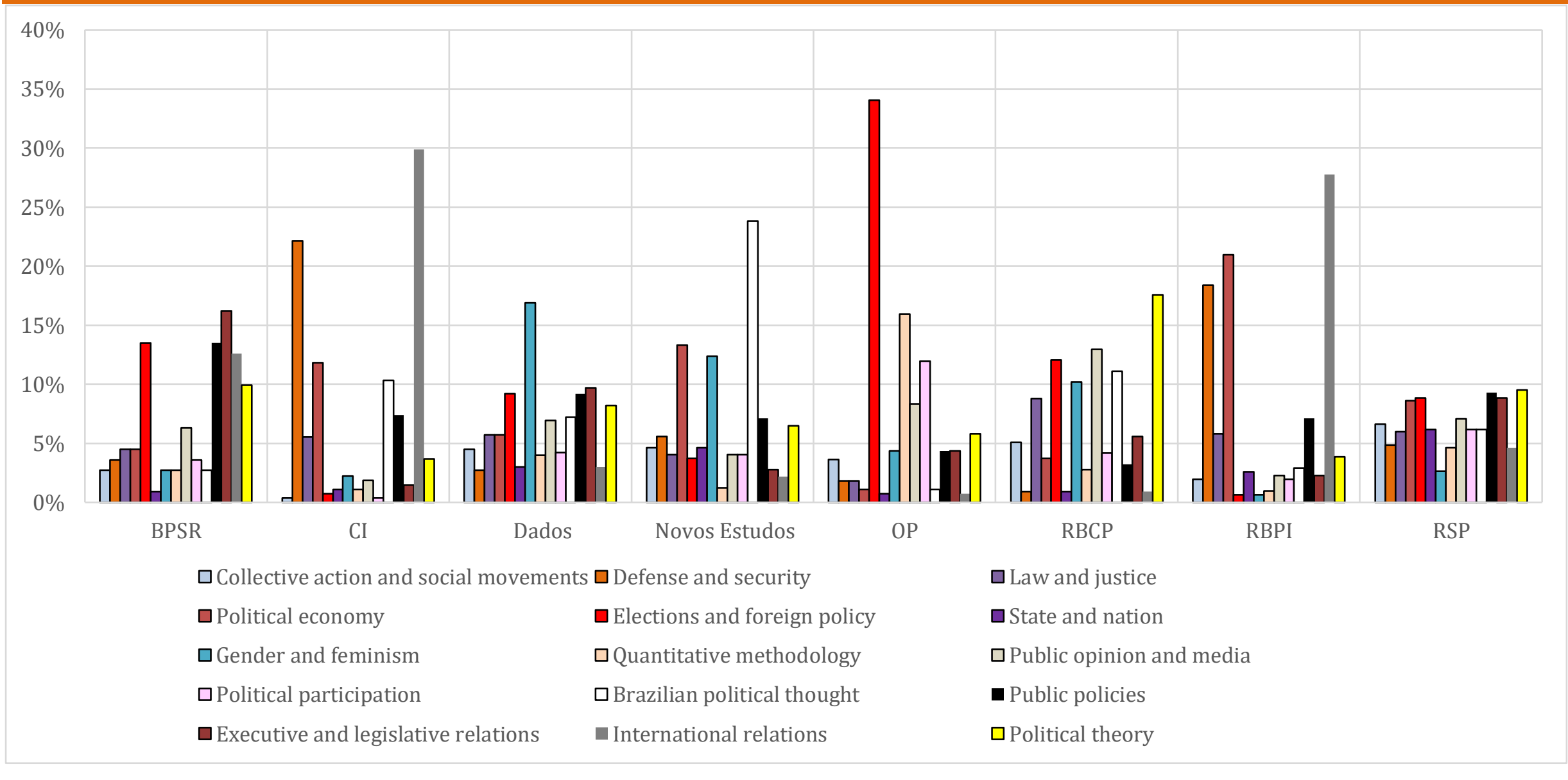

Source: Elaborated by the authors. 
Graph 04. Distribution of women and men as first authors by topic

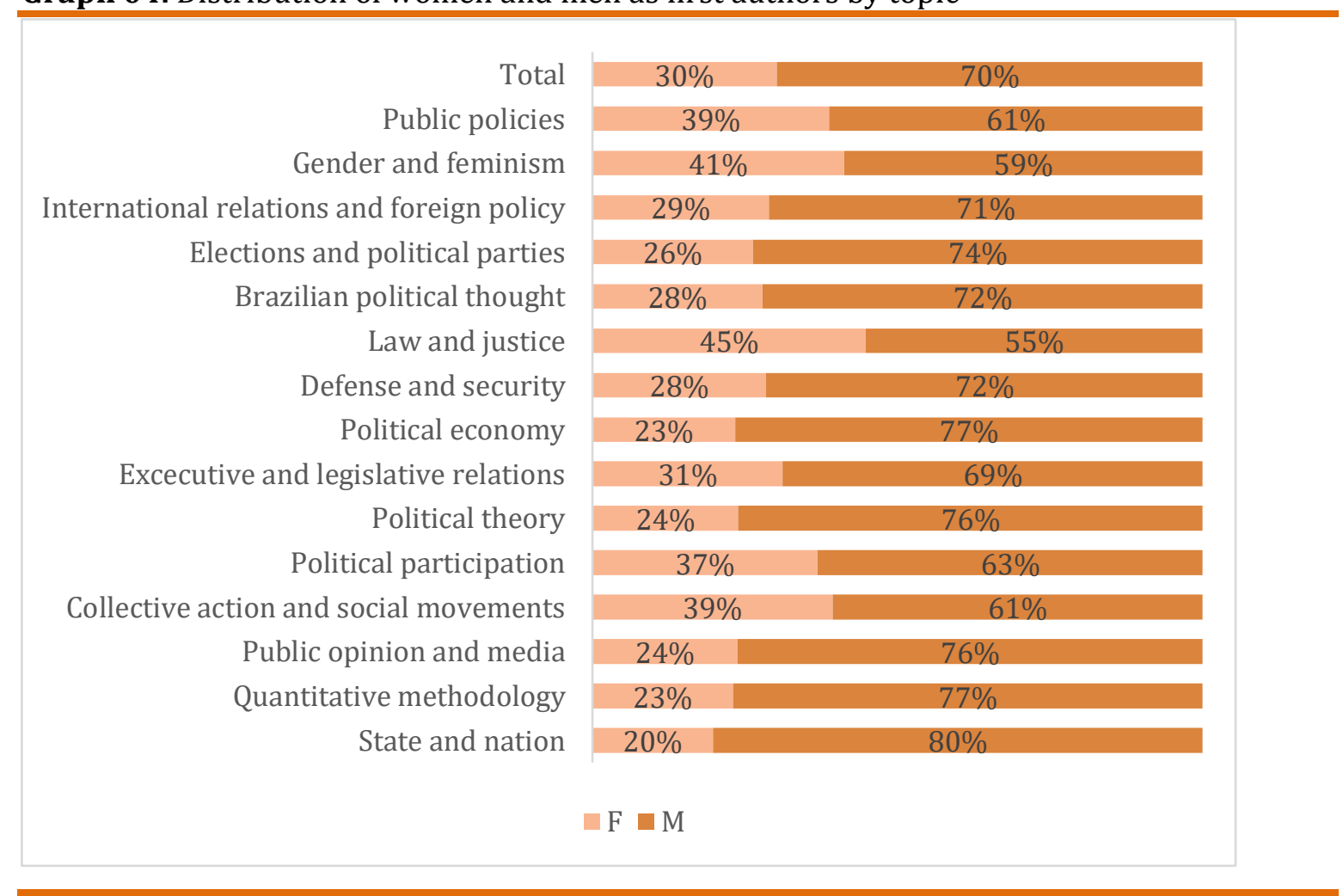

Source: Elaborated by the authors.

While the results indicate a clear horizontal division of labor, the same is not true for the vertical division. Graph 04 shows that gendered patterns of publication vary between topics; it also indicates that women are not necessarily overrepresented among scholars in those topics with a lower status in the journals. The topic with the worst publication performance, as shown in Graph 03, is 'state and nation', which also has the lowest proportion of women as first authors. In contrast, works on 'public policies' and 'gender and feminism' - topics with a substantial percentage of women as first authors - are regularly published.

To capture the potential effects of the journals' different editorial processes and proclivities, we examined the gender ratio of the first authors in the eight journals of our sample (Graph 05). The results show that the gender ratio in each journal does not deviate much from the average (30.2\%). These results suggest that the average gender imbalance that was found is unlikely to be the result of discriminatory procedures of one or more journals that were examined. 
Graph 05. Distribution of women and men as first authors by journal

\begin{tabular}{|c|c|c|}
\hline \multirow[b]{3}{*}{ Revista Brasileira de Política Internacional } & $23,4 \%$ & $76,6 \%$ \\
\hline & $26,6 \%$ & $73,4 \%$ \\
\hline & $28,1 \%$ & $71,9 \%$ \\
\hline Revista de Sociologia e Política & $28,9 \%$ & $71,1 \%$ \\
\hline Dados & $30,8 \%$ & $69,2 \%$ \\
\hline Opinião Pública & $31,9 \%$ & $68,1 \%$ \\
\hline Revista Brasileira de Ciência Política & $33,3 \%$ & $66,7 \%$ \\
\hline Contexto Internacional & $36,5 \%$ & $63,5 \%$ \\
\hline & $\square \mathrm{F} \square \mathrm{M}$ & \\
\hline
\end{tabular}

Source: Elaborated by the authors.

With such findings, it is convenient to ask whether the representation of women in each journal was not being affected by the journal's preference for specific topics ${ }^{9}$. Graph 06 shows, for each journal, the relationship between the percentage of articles authored by women (y-axis) and the percentage of published articles on the five topics in which women publish more: law and justice, gender and feminism, collective action and social movements, public policies, and political participation (xaxis). As we can see, the journals that are closely linked to the topic of international relations publish relatively few articles addressing those topics most favored by women. However, 'Contexto Internacional' publishes relatively more articles by female authors than 'Revista Brasileira de Política Internacional'. 'Dados', in turn, is the journal that most published articles on topics where women are better represented and the fourth that most published female authors, suggesting that its gender diversity may be the result of its receptivity to a wider range of topics. Despite these exceptions,

${ }^{9} \mathrm{We}$ are grateful to one of the anonymous reviewers of this article for suggesting this analysis.

$$
\text { (2021) } 15 \text { (3) =0002-22/33 }
$$


the results suggest that the inclusion of female authors seems to follow the journals' receptivity to the five topics in which women are better represented.

Graph 06. Percentage of articles authored by women by the percentage of published articles on the five subfields with greater female representation in journals

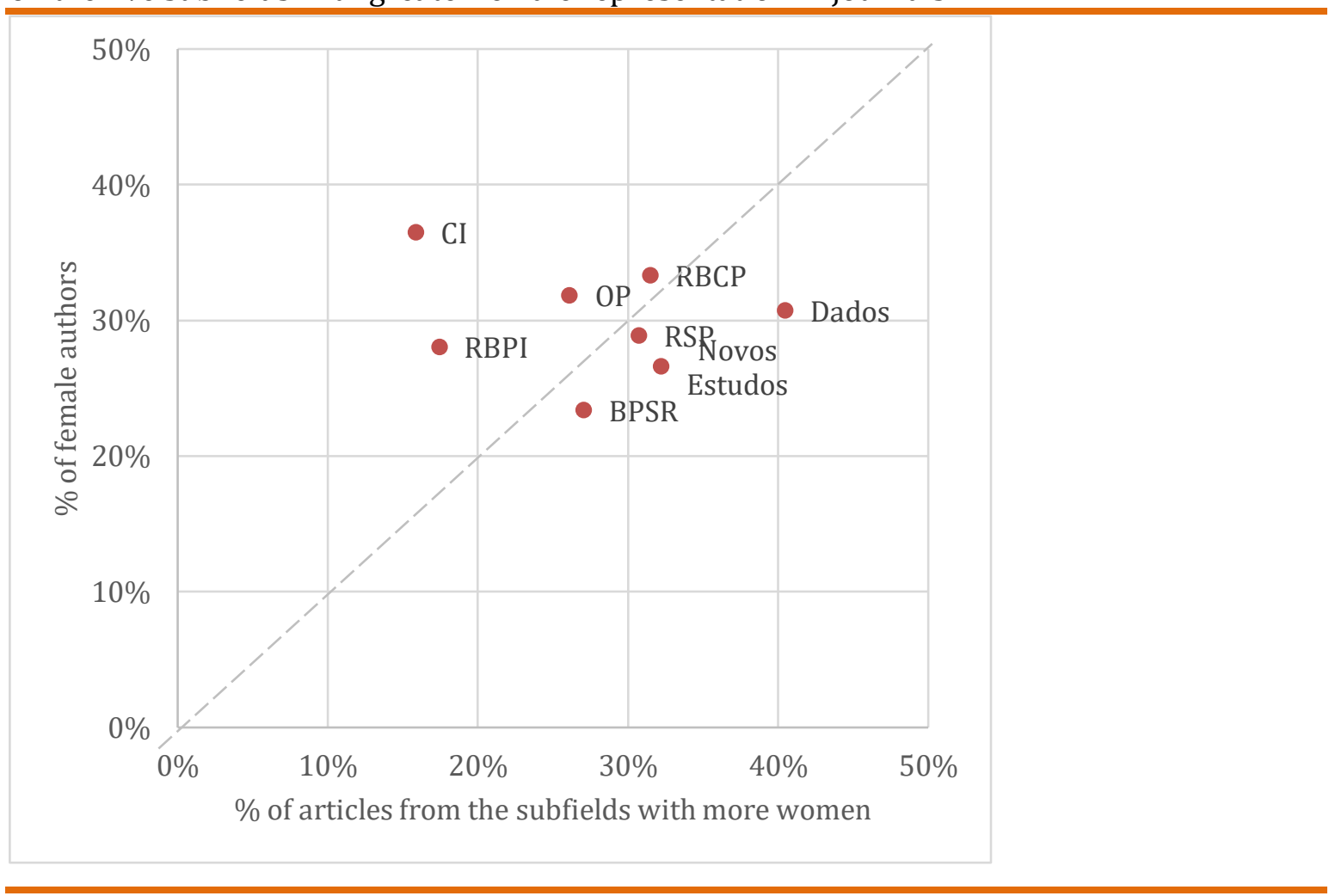

Source: Elaborated by the authors.

\section{Conclusions}

Political science has not only developed as one of the most male disciplines within the social sciences, but it has also been slow in incorporating gender perspectives in the discipline's studies (ACKER, 1990; BIROLI, 2016; CARPIUC, 2016; FREIDENBERG, 2018; MATOS, 2016). In this article, we sought to contribute to the debate on gender inequalities within the scientific community. The goal was to verify whether there is a gendered division of labor across the topics within Brazilian political science. For that, we identified the topics associated with 2,363 articles from the most prominent political science journals, as well as the distribution of male and female authors in each journal. Although women are the minority in all topics, the results corroborate the existence of a horizontal division of labor among scholars, or, in other 
words, the scholars' engagement to the topics in political science follows a gendered pattern.

According to the international literature that was examined in the first section, one of the causes of gender inequalities in submissions and authorship in journals is the infrequent publication of works that focus on topics in which women are more engaged. Our analysis of eight Brazilian academic journals ${ }^{10}$ indicate that this is not the case for Brazilian political science. Overwhelmingly male topics, such as 'state and nation', were rarely published. On the other hand, 'gender and feminism' was relatively frequently published. After hierarchically classifying the topics based on their publication rates in journals and defining this classification as an indicator of 'status', we did not find a clear vertical division of labor within the discipline.

Our results demonstrate that it is essential to observe in detail the context of each country. The thematic patterns displayed by Brazilian articles, for example, differ from those Key and Sumner (2019) identified in articles published elsewhere. Another difference seems to be in the interactions raised by the specialties available in the journals. Also, there is no political science journal that is specially dedicated to gender in Brazil. Brazilian journals that are focused on gender studies, such as 'Pagu' and 'REF', are interdisciplinary and generally unappealing to political scientists, which could explain why established political science journals are increasingly publishing works on gender. American political science, in contrast, has journals such as 'Women and Politics', one of the very few prestigious journals in the discipline with a majority of female authors (YOUNG, 1995).

It is also important to consider the relationship between the relative prestige and recognition associated with each topic in the discipline and the gender balance within it. If we take the average percentage of women as first authors as a threshold $(30,2 \%)$, we see that except for 'public policies', the topics above this threshold (i.e., those where female authors are better represented) are less established topics, such as 'right and justice', 'gender and feminism', 'collective action and social movements', and 'political participation'. While the topic 'executive-legislative relations' practically meets the threshold value, the rest fall below it. Some of the topics in which male

\footnotetext{
10'Brazilian Political Science Review' (BPSR), 'Contexto Internacional', 'DADOS', 'Novos Estudos', 'Opinião Pública', 'Revista Brasileira de Ciência Política', 'Revista Brasileira de Política Internacional', and 'Revista de Sociologia e Política'.
} 
overrepresentation is higher are also those that are better established in the discipline, such as 'international relations and foreign policy', 'Brazilian political thought', 'elections and political parties', 'political theory', 'public opinion and media', 'political economy', 'quantitative methodology', and 'state and nation'. Except for the quite specialized topic 'defense and security', all the other topics that fall below the threshold are, so to speak, mainstream, as they have been present in the discipline's curriculums and research agendas for decades, both in Brazil and in other countries.

In conclusion, we identified two different publication patterns associated with the gendered division of labor in Brazilian political science. Although Brazilian political science journals are frequently publishing works from those topics in which women are more engaged ('gender and feminism', for example), the gendered division of labor is still thriving in the Brazilian political science community - with men far in the lead in mainstream topics. Once our results have suggested that Brazilian journals do not give preference to publishing overly male topics of research, the causes of the gender gap in publication rates for men and women and the solutions to tackle it remain to be found.

Translated by Karin Blikstad Submitted on October 19, 2019 Accepted on July 21, 2020

\section{References}

ABELS, Gabriele and WOODS, Dorian R. (2015), The status of women in German political science. European Political Science. Vol. 14, pp. 87-95.

ABU-LABAN, Yasmeen; SAWER, Marian, and ST-LAURENT, Mathieu (2018), IPSA Gender and Diversity: Monitoring Report 2017. Montreal: IPSA. 36 pp..

ACKER, Joan (1990), Hierarchies, jobs, bodies: a theory of Gendered Organizations. Gender and Society. Vol. 05, № 02, pp. 139-158.

AKHTAR, Parveen; FAWCETT, Paul; LEGRAND, Tim; MARSH, David, and TAYLOR, Chloe (2005), Women in the Political Science Profession. European Political Science. Vol. 04 , № 03 , pp. 242-255.

ALLEN, Nicholas and SAVIGNY, Heather (2016), Experiencing gender in UK political science: the results of a practitioner survey. The British Journal of Politics and International Relations. Vol. 18, № 04, pp. 997-1015.

AMERICAN POLITICAL SCIENCE ASSOCIATION (2011), Political Science in the 21st Century. Washington: The American Political Science Association. 74 pp.. 
AMERICAN POLITICAL SCIENCE ASSOCIATION (APSA) (2004), Women's advancement in Political Science. Washington: American Political Science Association. 66 pp..

BARROS, Antonio Teixeira de and SILVA, Lucas (2017), A mídia como objeto de estudo da ciência política brasileira: análise da produção em periódicos qualificados. Teoria e Sociedade. Vol. 52, № 02, pp. 39-72.

BATES, Stephen; JENKINS, Laura and PFLAEGER, Zoe (2012), Women in the profession: composition of UK Political Science Departments by sex. Politics. Vol. 32, № 03, pp. 139-152.

BIROLI, Flávia (2016), Divisão sexual do trabalho e democracia. DADOS. Vol. 59, № 03, pp. 719-754.

BRANDES, Lisa; BUKER, Eloise; BURGESS, Susan; COOK, Constance; FLAMMANG, Janet; GEIGER, Shirley; OKIN, Susan; YOON, Bang-Soon and ACKELSBERG, Martha (2001), The status of women in Political Science: female participation in the professoriate and the study of women and Political Science in the discipline. Political Science and Politics. Vol. 34, № 02, pp. 319-326.

BREUNING, Marijke and LU, Kelan (2010), Participation by women in ISA Annual Meetings, 2005-2009. International Studies Perspectives. Vol. 11, № 03, pp. 242254.

BREUNING, Marijke and SANDERS, Kathryn (2007), Gender and journal authorship in eight prestigious Political Science Journals. Political Science and Politics. Vol. 40, № 02, pp. 347-351.

BRINGEL, Breno (2016), Nota editorial: política e fluxo editorial da DADOS. DADOS. Vol. 59, № 02, pp. 311-321.

BROWN, Nadia; HORIUCHI, Yusaku; HTUN, Mala, and SAMUELS, David (2019), Gender gaps in perceptions of Political Science Journals. Political Science and Politics. Vol. 53, № 01, pp. 114-121.

BULCOURF, Pablo; MÁRQUEZ, Enrique Gutiérrez, and CARDOZO, Nelson (2015), Historia y desarrollo de la Ciencia Política en América Latina: reflexiones sobre la constitución del campo de estudios. Revista de Ciencia Política. Vol. 35, № 01, pp. 179-199.

CAMPOS, Luiz Augusto; FERES JÚNIOR, João, and GUARNIERI, Fernando (2017), 50 Anos da Revista DADOS: uma análise bibliométrica do seu perfil disciplinar e temático. DADOS. Vol. 60, № 03, pp. 623-661.

CANDIDO, Marcia Rangel; FERES JUNIOR, João, and CAMPOS, Luiz Augusto (2019), Desigualdades na elite da ciência política brasileira. CIVITAS. Vol. 19, № 03, pp. 564-582. 
CAO, Juan; XIA, Tian; LI, Jintao; ZHANG, Yongdong, and TANG, Sheng (2009), A densitybased method for adaptive LDA model selection. Neurocomputing. Vol. 72, № 07/09, pp. 1775-1781.

CARPIUC, Cecília Rocha (2016), Women and diversity in Latin American political science. European Political Science. Vol. 15, pp. 457-475.

CORDEIRO, Marina (2017), 0 tempo desigualmente distribuído: gênero e carreira acadêmica entre cientistas sociais. Anais do XV Encontro Nacional da Associação Brasileira de Estudos do Trabalho. Available at <http://abet2017.com.br/wpcontent/uploads/2015/09/Paper-ABET-2015-Marina-Cordeiro.pdf>. Accessed on February, 14, 2020.

COLGAN, Jeff (2017), Gender bias in International Relations graduate education? New evidence from syllabi. Political Science \& Politics. Vol. 50, № 02, pp. 456-460.

CURTIN, Jennifer (2013), Women and political science in New Zealand: the state of the discipline. Political Science. Vol. 65, № 01, pp. 63-83.

DINIZ, Debora and FOLTRAN, Paula (2004), Gênero e feminismo no Brasil: uma análise da Revista Estudos Feministas. Estudos Feministas. Vol. 12, № esp., pp. 245-253.

DION, Michelle and MITCHELL, Sara (2019), How many citations to women is 'enough'? Estimates of gender representation in Political Science. Political Science \& Politics. Vol. 53, № 01, pp. 107-113.

DION, Michelle; SUMNER, Jane Lawrence, and MITCHELL, Sara McLaughlin (2018), Gendered citation patterns across Political Science and Social Science Methodology fields. Political Analysis. Vol. 26, № 03, pp. 312-327.

DJUPE, Paul A; SMITH, Amy Erica, and SOKHEY, Anand Edward (2018), Explaining gender in the Journals: how submission practices affect publication patterns in Political Science. Political Science \& Politics. Vol. 52, № 01, pp. 71-77.

ECPR (2018), Gender Study. Available at <https:// ecpr.eu/Filestore/CustomContent/Publications/Gender\%20Study/Gender _Study_2018. pdf>. Accessed on October, 01, 2019.

ECPR (2017), Gender Study. Available at <https:// ecpr.eu/Filestore/CustomContent/Publications/Gender\%20Study/Gender_Study_20 17.pdf>. Accessed on October, 01, 2019.

ECPR (2017), Gender Study. Available at <https:// ecpr.eu/Filestore/CustomContent/Publications/Gender\%20Study/Gender_Study_20 16.pdf>. Accessed on October, 01, 2019.

ELIZONDO, Arantxa (2015), The status of women in Spanish political science. European Political Science. Vol. 14, № 02, pp. 96-104. 
EVANS, Heather and MOULDER, Ashley (2011), Reflecting on a decade of women's publications in four top Political Science Journals. Political Science \& Politics. Vol. 44, № 04, pp. 793-798.

FERGUSON, Lucy (2013), Gender, work, and the sexual division of labor. In: The Oxford Handbook of Gender and Politics. Edited by WAYLEN, Georgina; CELIS, Karen; KANTOLA, Johanna, and WELDON, S. Laurel. New York: Oxford University Press.

FERnÁNDEZ, María de los Ángeles (2006), Mujer y Ciencia Política en Chile: ¿algo nuevo bajo el sol?*. Política. Vol. 46, pp. 261-289.

FREIDENBERG, Flavia D. (2018), Gender Blindness in Latin American Political Science. Ameryka Laciñska. Vol. 03, № 101, pp. 50-66.

GOODWIN, Mark; BATES, Stephen Holden, and McKAY, Stephen (2020), Electing to do women's work? Gendered divisions of labor in U.K. select committees, 1979-2016. Politics \& Gender. pp. 01-33.

KANTOLA, Johanna Elina (2015), Political Science as a gendered discipline in Finland. European Political Science. Vol. 14, № 02, pp. 79-86.

KANTOLA, Johanna Elina (2008), Why do all the women disappear? Gendering processes in a Political Science Departement. Gender, Work and Organization. Vol. 15, № 02, pp. 202-225.

KERGOAT, Danièle (2009), Divisão sexual do trabalho e relações sociais de sexo. In: Dicionário Crítico do Feminismo. Edited by HIRATA, Helena; LABORIE, Françoise; DOARÉ, Hélène Le, and SENOTIER, Danièle. São Paulo: Editora UNESP. pp. 67-75.

KEY, Ellen M. and SUMNER, Jane L. (2019), You research like a girl: gendered research agendas and their implications. Political Science \& Politics. Vol. 52, № 04, pp. 663668.

KONIG, Thomas and ROPERS, Guido (2018), Gender and editorial outcomes at the American Political Science Review. Political Science \& Politics. Vol. 51, № 04, pp. 849-853.

LEITE, Fernando (2016), Tradições disciplinares e tradições intelectuais na trajetória da ciência política brasileira. Cadernos CRH. Vol. 29, № 78, pp. 587-605.

LEITE, Fernando and CODATO, Adriano (2013), Autonomização e institucionalização da Ciência Política brasileira: o papel do sistema Qualis-Capes. Agenda Política. Vol. 01, № 01, pp. 01-21.

LINDROOS, Kia; CARDINAL, Linda; SAWER, Marian, and ST-LAURENT, Mathieu (2014), IPSA Gender Monitoring Report 2013. The International Political Science Association. 24 pp.. 
MACEDO, Felipe Brito and CANDIDO, Marcia Rangel (2019), Análise das assimetrias regionais da produção brasileira em ciência política e sociologia a partir do sistema Qualis Capes. Paper. 43ํㅡㄹ Encontro Anual da ANPOCS.

MARQUES, Danusa (2016), Cadê as mulheres no 10ํㅡㄹ Encontro da ABCP? Blog Demodê. Available at <https://grupo-demode.tumblr.com/post/150165099618/ cad\%C3\%AA-as-mulheres-no-10\%C2\%BA-encontro-da-abcp>. Accessed on September, 01, 2019.

MATHEWS, A. Lanathea and ANDERSEN, Kristi (2001), A gender gap in publishing? Women's representation in edited Political Science books. Political Science \& Politics. Vol. 34, № 01, pp. 143-147.

MATONYTE, Irmina; SAWER, Matian, and ST-LAURENT, Mathieu (2012), IPSA Gender Monitoring Report 2011. Montreal: The International Political Science Association. 26 pp..

MATOS, Marlise (2016), A Institucionalização acadêmica dos estudos de gênero e feministas na ciência política brasileira. In: A Ciência Política no Brasil: 1960-2015. Edited by AVRITZER, Leonardo; MILANI, , Carlos R. S., and BRAGA, Maria do Socorro. Rio de Janeiro: Editora FGV. pp. 347-391.

MENDES, Marcos Vinicius Isaias and FIGUEIRA, Ariane Cristine Roder (2019), Women's scientific participation in Political Science and International Relations in Brazil. Revista de Estudos Feministas. Vol. 27, № 02, pp. 01-13.

MICHETTI, Heloísa Helena and MICELI, María Teresa (1969), A situação do ensino e pesquisa de ciência política no Brasil. Revista de Ciência Política. Vol. 02, № 04, pp. 89-110.

MITCHELL, Sara McLaughlin; LANGE, Samantha, and BRUS, Holly (2013), Gendered citation patterns in International Relations Journals. International Studies Perspectives. Vol. 14, № 04, pp. 485-492.

MONROE, Kristen Renwick and CHIU, William F. (2010), Gender equality in the Academy: the pipeline problem. Political Science \& Politics. Vol. 43, № 02, pp. 303308.

NICOLAU, Jairo and OLIVEIRA, Lilian (2017), Political Science in Brazil: an analysis of academic articles (1966-2015). Sociologia e Antropologia. Vol. 07, № 02, pp. 371393.

PANSARDI, Pamela and VERCESI, Michelangelo (2017), Party gate-keeping and women's appointment to Parliamentary Committees: evidence from Italian Case. Parliamentary Affairs. Vol. 70, pp. 72-83.

PETERSON, David (2018), Author gender and editorial outcomes at political behavior. Political Science \& Politics. Vol. 51, № 04, pp. 866-869. 
REID, Rebecca and CURRY, Todd (2019), Are we there yet? Addressing diversity in Political Science subfields. Political Science \& Politics. Vol. 52, № 02, pp. 281-286.

SAMUELS, David (2018), Gender and editorial outcomes at Comparative Political Studies. Political Science \& Politics. Vol. 51, № 04, pp. 854-858.

SAMUELS, David and TEELE, Dawn (2018), New medium, same story: gender gaps in book publishing. Political Science \& Politics. Vol. 54, № 01, pp. 131-140.

SCARPA, Alice Duarte (2017), Técnicas de processamento de linguagem natural aplicadas às Ciências Sociais. Master's dissertation. Escola de Matemática. Fundação Getúlio Vargas.

STEGMAIER, Mary; PALMER, Barbara, and van ASSENDELFT, Laura (2011), Getting on the board: the presence of women in political science journal editorial positions. Political Science \& Politics. Vol. 44, № 04, pp.799-804.

SZWAKO, José; DOWBOR, Monika, and ARAÚJO, Ramon (2020), A produção de artigos acadêmicos sobre movimentos sociais publicados nos periódicos brasileiros (2000-2017): tendências e inovações. BIB - Revista Brasileira de Informação Bibliográfica. № 92, pp. 01-22.

TEELE, Dawn Langan and THELEN, Kathleen (2017), Gender in the journals: publication patterns in Political Science. Political Science \& Politics. Vol. 50, № 02, pp. 433-447.

TUDOR, Carissa and YASHAR, Deborah (2018), Gender and the editorial process: World Politics, 2007-2017. Political Science \& Politics. Vol. 51, № 04, pp. 870-880.

VAN ASSENDELFT, Laura; BALDWIN, Mary; FORTNA, Page; GAY, Claudine, and SANBONMATSU, Kira (2019), Would I do this all over again? Mid-career voices in Political Science. Washington: Political Science Education and the Profession. 46 pp...

WILLIAMS, Helen; BATES, Stephen; JENKINS, Laura; LUKE, Darcy, and ROGERS, Kelly (2015), Gender and journal authorship: an assessment of articles published by women in three top British political science and international relations journals. European Political Science. Vol. 14, № 02, pp. 116-130.

YOUNG, Cheryl (1995), An assessment of articles published by women in 15 top political science journals. Political Science and Politics. Vol. 28, № 03, pp. 525-533. 


\section{Page 18:}

Where it reads:

Graph 01. Percentage of texts in the corpus according to the assigned predominant topic "Pensamento politico"

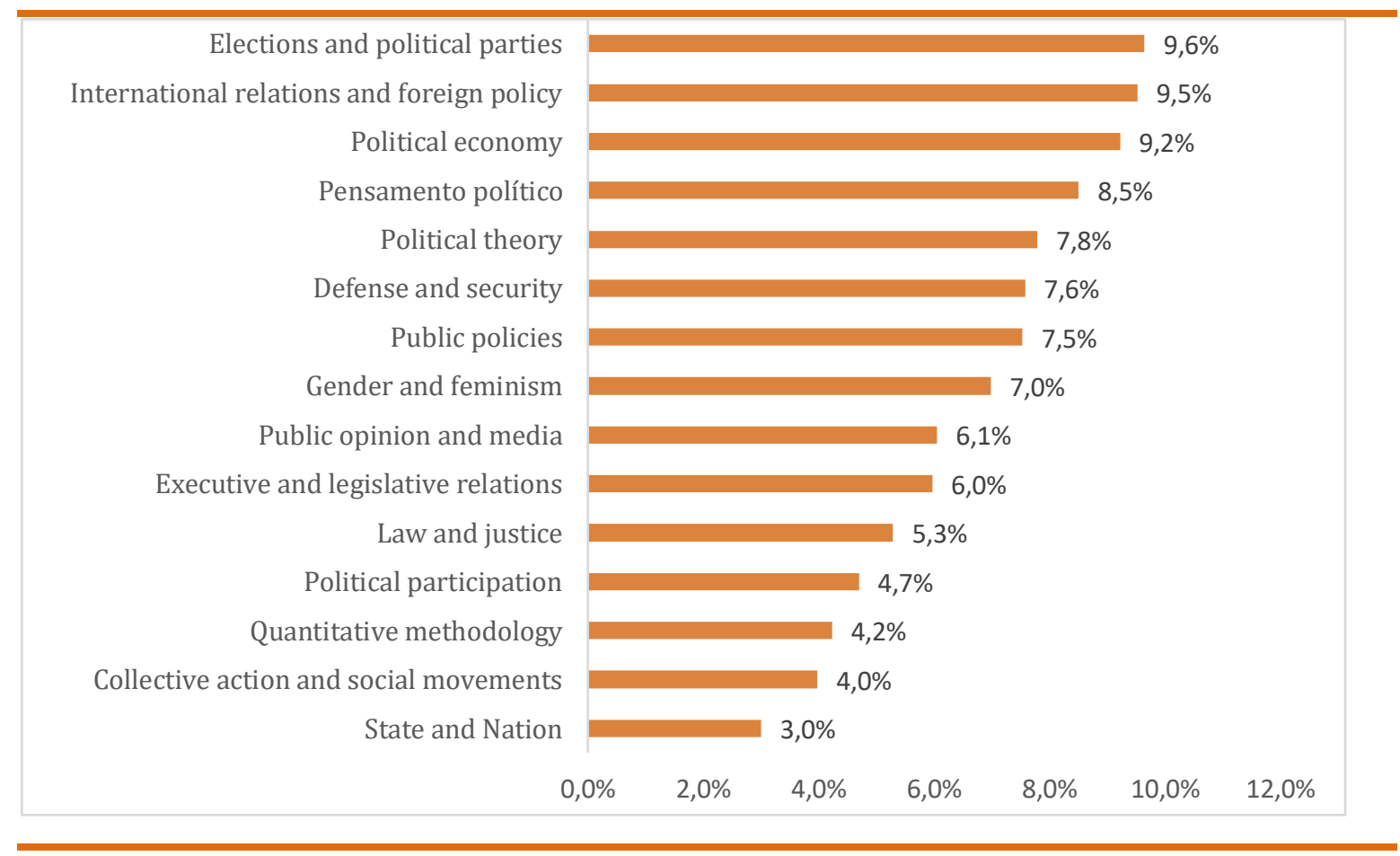

\section{Read on:}

Graph 01. Percentage of texts in the corpus according to the assigned predominant topic "Brazilian political thought"

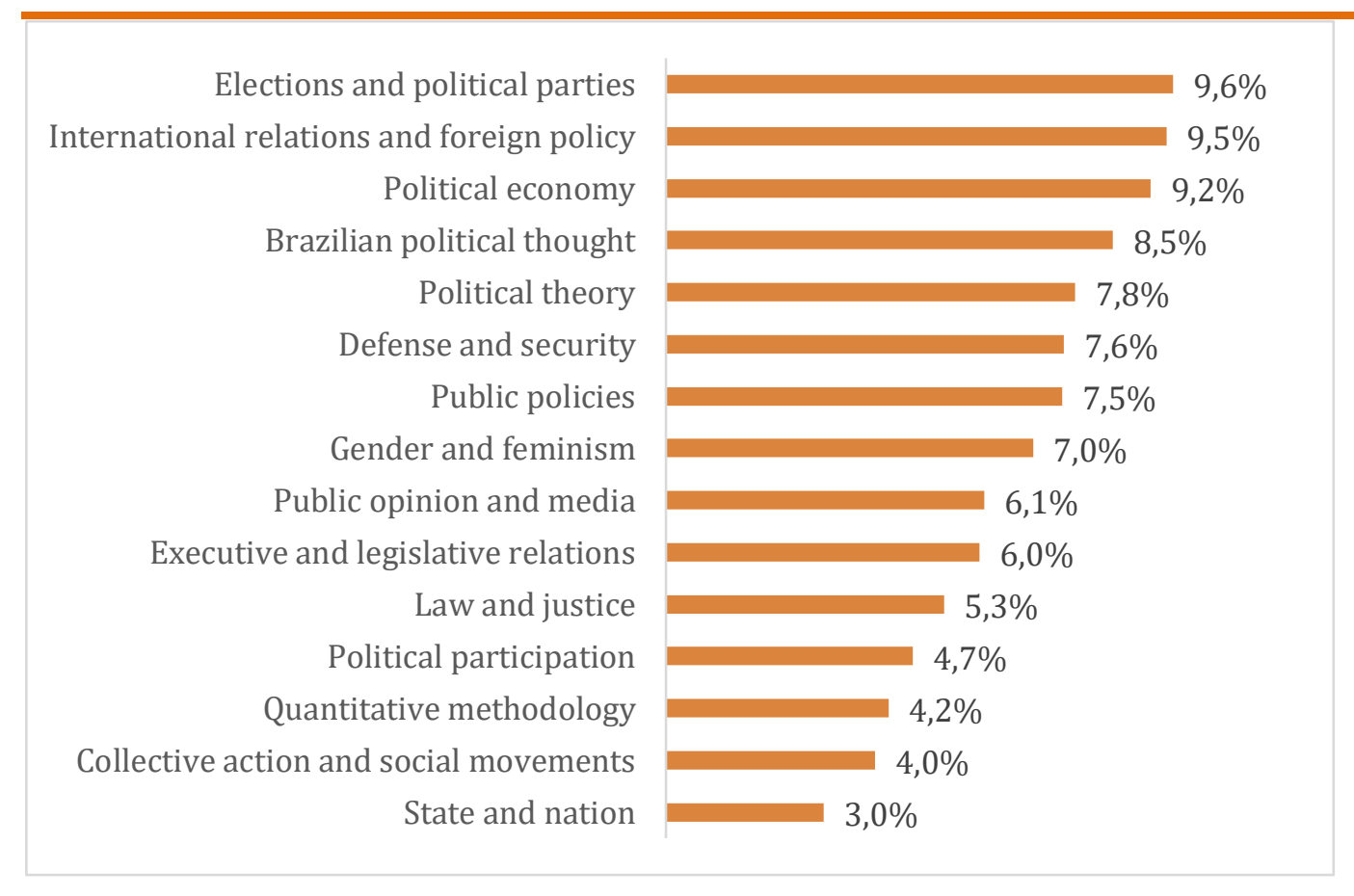


Page 20:

Where it reads:

Graph 03. Percentage distribution of articles according to the assigned topic and journal

"Elections and foreign policy" e "International relations"

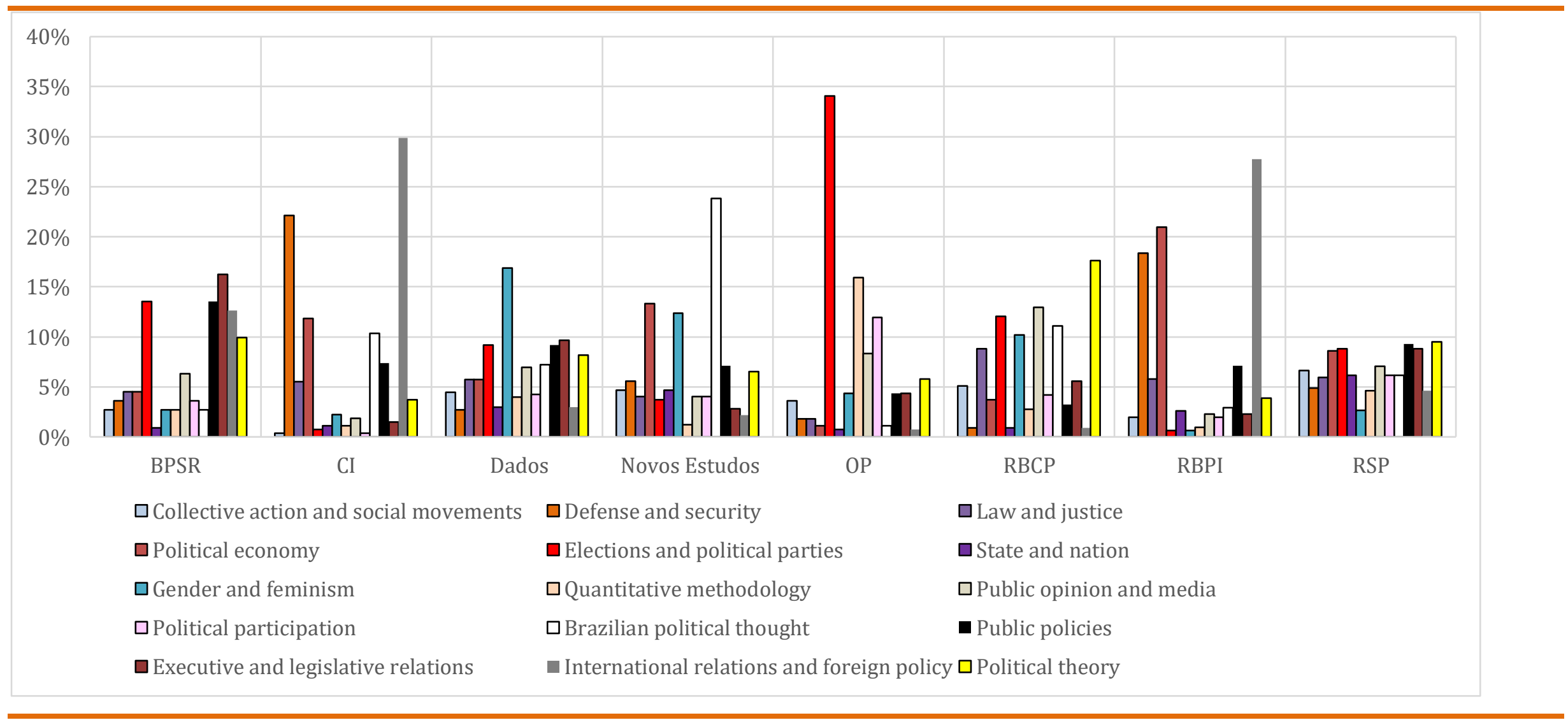




\section{Read on}

Graph 03. Percentage distribution of articles according to the assigned topic and journal

"Elections and political parties" e "International relations and foreign policy"

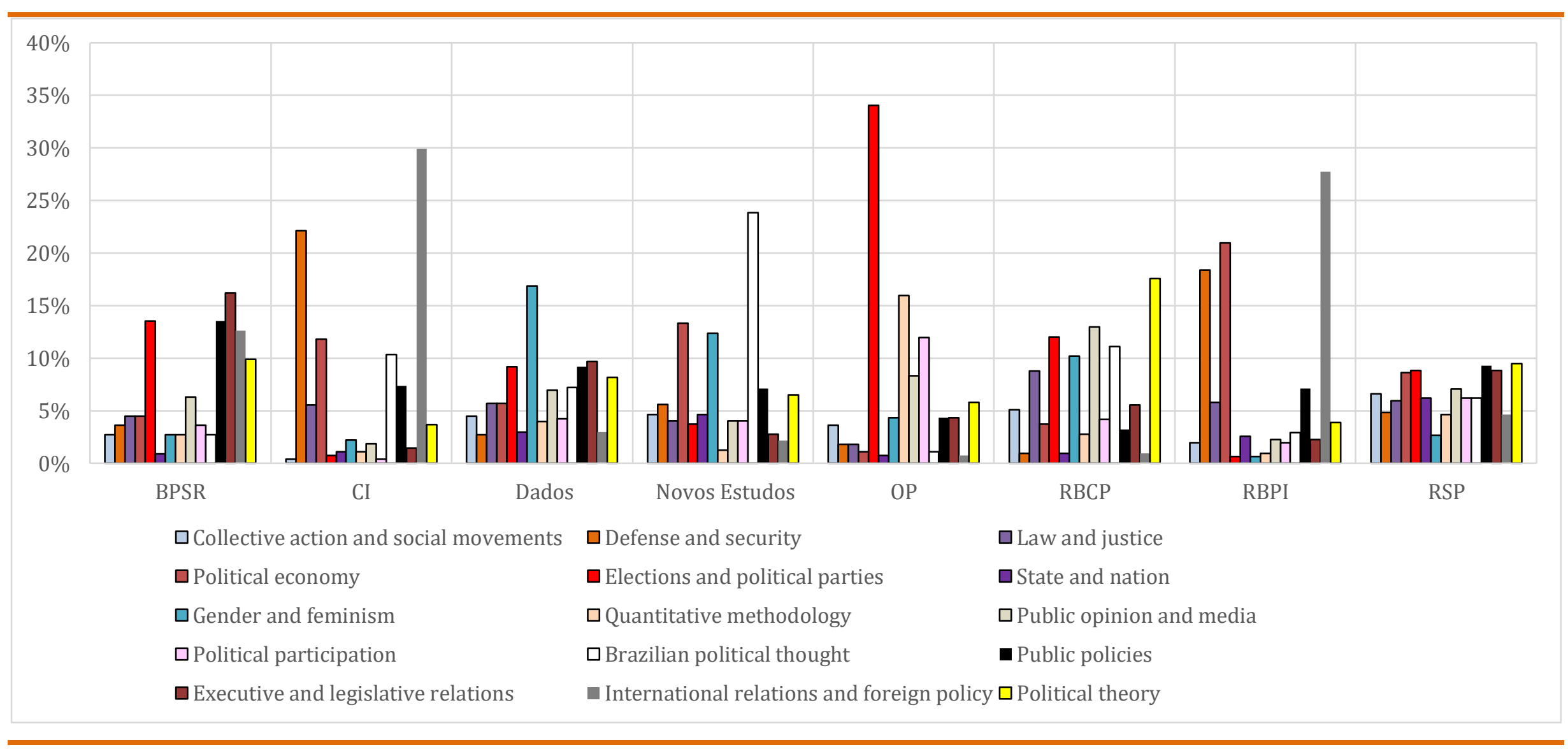

